\title{
MODERN SLAVERY IN INDONESIA: BETWEEN NORMS AND IMPLEMENTATION
}

\author{
Savira Dhanika Hardianti ${ }^{1}$ \\ Faculty of Law Brawijaya University
}

\begin{abstract}
People in the 21st century are still sold like objects, forced to work for little or no wages paid and at the mercy of 'employer'. Global Slavery Index (GSI) in 2013 showed that an estimated 29.8 million people living in modern-day slavery. In Indonesia there are 210970 people living in slavery. Although Indonesia has some of the laws governing modern slavery are included in the Law of Anti-Trafficking. This paper tries to find the norms and implementation in practice of modern slavery. How norms are implemented by the government and what barriers to enforce the law.
\end{abstract}

Keywords: Forced Labor, Slavery, Human Rights, Human Trafficking

\section{INTRODUCTION}

Slavery is a problem that should be a concern to the international community as a violation of human rights. Slavery is the status or condition of a person over whom any or all of the powers attaching to the right of ownership are carried out. The international prohibition on slavery is absolute; there are no exceptions (as there are for forced labor). Slavery is an institution in which the slave master's exercise of the rights of ownership destroys the human personality - the person as a bearer of rights - and reduces the slave to chattel, without rights. Human rights are the basic rights and freedoms that belong to every person in the world. Based on United Nations Universal Declaration of Human Right 1948 (UDHR), No one shall be held in slavery and the slave trade shall be prohibited in all their forms. But in reality, some people now in the 21 st century are still sold like objects, forced to work for less Money or not paid at all and

\footnotetext{
1 This writer is a student at faculty of Law, Brawijaya University. Email address at saviradhanika@ymail.com
} 
at the complete mercy of their 'employers'. ${ }^{2}$

Definitions of modern slavery hardly found in any literature. But is in slavery if they are:

1. Forced to work - through mental or physical threat;

2. Owned or controlled by an 'employer', usually through mental or physical abuse or the threat of abuse;

3. Dehumanized, treated as a commodity or bought and sold as 'property';

4. Physically constrained or has restrictions placed on his/her freedom of movement.

Global Slavery Index (GSI) in 2013 showed that an estimated 29.8 million people were forced to work and paid less than they should accept or unpaid.

Table $1:^{3}$

Countries with the highest estimate population in Modern Slavery

\begin{tabular}{|c|c|c|c|c|}
\hline Country Name & Rank & $\begin{array}{c}\text { Estimate of } \\
\text { Population in } \\
\text { Modern } \\
\text { Slavery }\end{array}$ & $\begin{array}{c}\text { Lower } \\
\text { Range of } \\
\text { Estimate }\end{array}$ & $\begin{array}{c}\text { Upper Range } \\
\text { of Estimate }\end{array}$ \\
\hline India & 1 & $13,956,010$ & $13,300,000$ & $14,700,000$ \\
\hline China & 2 & $2,949,243$ & $2,800,000$ & $3,100,000$ \\
\hline Pakistan & 3 & $2,127,132$ & $2,000,000$ & $2,200,000$ \\
\hline Nigeria & 4 & 701,032 & 670,000 & 740,000 \\
\hline Ethiopia & 5 & 651,110 & 620,000 & 680,000 \\
\hline Russia & 6 & 516,217 & 490,000 & 540,000 \\
\hline Thailand & 7 & 472,811 & 450,000 & 500,000 \\
\hline $\begin{array}{c}\text { Democratic } \\
\text { Republic of the } \\
\text { Congo }\end{array}$ & 8 & 462,327 & 440,000 & 490,000 \\
\hline Myanmar & 9 & 384,037 & 360,000 & 400,000 \\
\hline
\end{tabular}

${ }^{2}$ What Is Modern Slavery, (6th April 2014)

<http://www.antislavery.org/english/slavery_today/what_is_modern_slavery.aspx >

${ }^{3}$ Ibid 


\begin{tabular}{|c|c|c|c|c|} 
Bangladesh & 10 & 343,192 & 330,000 & 360,000 \\
\hline Tanzania & 11 & 329,503 & 310,000 & 350,000 \\
\hline Sudan & 12 & 264,518 & 250,000 & 280,000 \\
\hline Nepal & 13 & 258,806 & 250,000 & 270,000 \\
\hline Uganda & 14 & 254,541 & 240,000 & 270,000 \\
\hline Vietnam & 15 & 248,705 & 240,000 & 260,000 \\
\hline Indonesia & 16 & 210,970 & 200,000 & 220,000 \\
\hline
\end{tabular}

The table above shows that Indonesia is ranked 16 in modern slavery, with around 210,970 Indonesian people enslaved. Modern slavery practices in Indonesia can be seen in some companies where workers are treated like a slave, not like the other workers.

The forms of slavery are various. Some of the forms of slavery are Bonded Labor, Forced Labor, Descent-based slavery, Trafficking, Child slavery, early and Forced Marriage. This paper would be focused on Forced Labor. Forced labor is any work or services which people are forced to do against their will under the threat of some form punishment. Almost all slavery practices, including trafficking in people and bonded labor, contain some element of forced labor.

The worst case is always remembered as an act of Slavery in Indonesia is the case in Pot Plant, which is located in Tangerang, West Java, Indonesia. The owner gets 11 years after he was proven guilty of holding employees at his factory captive, including several minors, and make them work without being paid. They were also not allowed to change their clothes and all their belongings were confiscated by their employer. However, protecting human rights is one of the Indonesian Government responsibilities. Being a forced labor means living in a modern slavery. Therefore, this paper will try to answer: How is forced labor according to Indonesian law? What is Indonesian Government effort in combating forced labor? 


\section{LEGAL MATERIALS AND METHODS}

\section{A. Type of Research}

Type of research that is used by author in researching problems in this research is a norm. Normative research is a process to identify the rule of law, legal principle, even law doctrines in order to answer the law issue.

\section{B. Types of Legal materials}

\section{1) Primary Legal Materials}

Primary legal materials are an authoritative legal materials, which means has an authority. Primary legal materials used are:

a. The Slavery Convention 1926

b. Indonesian constitution 1945

c. Act number 39 year 1999 on Human Rights

d. Act Number 13 Year 2003 on Manpower

e. Act no 21 year 2007 on Eradication of the Criminal Act of the Trafficking in persons

f. Indonesian criminal code

\section{2) Secondary Legal Materials.}

Secondary legal materials that are used in this paper is the legal materials that explain the primary legal materials, in the form of literatures or books related to a modern form of slavery.

\section{3) Tertiary Legal Materials.}

Tertiary legal materials that are used in this paper is materials which could provide clues or explanations towards primary legal materials, such as dictionaries, 
articles, law journals and from the internet.

\section{Result and Discussion}

\section{Forced labor According to Indonesian Law}

Indonesia is a larger country with the population more than 200 million people, with

7, 15 million people unemployed. ${ }^{4}$ Poverty is almost everywhere and it makes them to accept a wide variety of work, and it could be one of the factors of human trafficking in Indonesia. We must remember that slavery is a type of human trafficking.

International concern with slavery and its suppression is the theme of many treaties, declarations and conventions of the nineteenth and twentieth centuries. The first of three modern conventions directly related to the issue is the Slavery Convention of 1926, drawn up by the League of Nations. ${ }^{5}$ Based on The Slavery Convention 1926 article 1, Slavery can be described as the status or condition of a person over whom any or all of the powers attaching to the right of ownership are exercised. People who forced to work and paid nothing is a kind of modern slavery. The regulation concerning about modern slavery is not just The Slavery Convention 1926, but also Suppelementary Slavery Convention, UN Trafficking Protocol, Abolition Forced Labor Protocol, and etc. It means since 1926 the world has agreed that no one shall be in slavery. Although Indonesia is one of UN members, but some of those conventions have not been ratified by The Indonesian Government. May 2014

${ }^{4}$ Official report of Central Bureau of Statistic of Manpower Affairs February 2014 No. 38/05/Th. XVII, 5

5 Factsheet No 14, Contemporarry Forms of Slavery $\quad\left(26^{\text {th }}\right.$ June 2014) <http://www.ohchr.org/Documents/Publications/FactSheet14en.pdf> 
Table $2:^{6}$

The Conventions Relevant to Modern Slavery

\begin{tabular}{|c|c|}
\hline INDONESIA & RATIFIED \\
\hline THE SLAVERY CONVENTION & NO \\
\hline $\begin{array}{c}\text { SUPPLEMENTARY SLAVERY } \\
\text { CONVENTION }\end{array}$ & NO \\
\hline UNTRAFFICKING PROTOCOL & YES \\
\hline $\begin{array}{c}\text { ABOLITION FORCED LABOR } \\
\text { CONVENTION (ACT NUMBER 19 } \\
\text { YEAR 1999) }\end{array}$ & YES \\
\hline $\begin{array}{c}\text { WORST FORMS OF CHILD LABOR } \\
\text { CONVENTION }\end{array}$ & YES \\
\hline $\begin{array}{c}\text { CRC OPTIONAL PROTOCOL ON } \\
\text { THE SALE OF CHILDREN }\end{array}$ & YES \\
\hline
\end{tabular}

From the table and explanation above shows that the slavery convention and supplementary slavery convention, which are the "main" conventions concerning about slavery has not been ratified by Indonesia. But it does not mean that Indonesia has no regulation about slavery practice. The Indonesian constitution year 1945 Article 28I (1) constitution of Indonesia ensures that:

The rights to life, freedom from torture, freedom of thought and conscience, freedom of religion, freedom from enslavement, recognition as a person before the law, and the right not to be tried under a law with retrospective effect are all human rights that cannot be limited under any circumstances.

Indonesian citizens are subjected to modern slavery in various forms. ${ }^{7}$

(1) No one shall be held in slavery or servitude

\footnotetext{
${ }^{6}$ The table is compiled from many resources.

7 Walk Free Fondation, 2013. Global Slavery Index 2013 : Indonesia $\left(6^{\text {th }}\right.$ April 2014) <http://www.globalslaveryindex.org/country/indonesia/>
} 
(2) Slavery, the slave trade and servitude shall be prohibited in all their forms

a. Occupational safety and health protection;

b. Protection against immorality and indecency;

"Slavery is the status or condition of a person who is under the ownership of another person. The slavery-like practice is the act to put someone under another person's power so that the person is not able to resist the job that is unlawfully commanded by another person. Even that person does not want to do it."

The penal code also gives punishment for the employer who does the slavery-like practices. Indonesian penal code (Kitab Undang-Undang Hukum Pidana) article 333 (1) stated that:

Any person who with deliberate intent and unlawfully deprives someone or keeps someone deprived of his liberty, shall be punished by a maximum imprisonment of eight years.

Those articles in Indonesian national law above shows that Indonesia ensures that no person shall be in enslavement, or in any forms of it. Indonesia has a faith to protect the human rights.

Global Slavery Index 2013 states that Corruption weakens Indonesia's response to modern slavery. ${ }^{8}$ However, to end the modern slavery practice, especially the forced labor practice, it needs government's attention to monitoring and to solve it.

\section{The Indonesian Government Effort in Combating Forced Labor}

The preamble of UDHR 1948 that was adopted on 10 December 1948 states that recognition of the inherent dignity and of the equal and inalienable rights of all members of the

\footnotetext{
${ }^{8}$ Walk Free Fondation, op.cit
} 
human family is the foundation of freedom, justice and peace in the world. ${ }^{9}$ The concept of human rights is related to the ethics and morals. ${ }^{10}$ Protecting human rights is not as easy as it seems. It does not only need the government, but also the other people to protect human rights, starts from respect to others.

To end the practice of forced labor means giving back the human dignity of the labor force. They will regain their lost desire and can build a better life. It will make manifest of human equality. Then there arose a question, how to put an end to this practice?

Over the past decade the Government of Indonesia has demonstrated a clear commitment to address human trafficking. It all can be shown when Indonesia adopted Anti-Trafficking Law and also founded "Task Force on Preventing and Handling Human Trafficking". This task force functioned to advocacy, socialization, monitoring the protection of human trafficking victims, monitoring law enforcement, reporting and evaluating. Besides that, The Indonesian government has been maximizing the task of the ministry of law and human rights and national police.

But even though Indonesian government has done so many things, the fact is combating forced labor is not easy. There are some problems handling human trafficking in Indonesia. Ledia Hanifa, member of the House of Representative Indonesia on her presentation stated that the sectorial budget bundling, lack of Number of Human Resources, and Insufficient Infrastructure are the main problems in handling human trafficking. Then again, Indonesia has more than 17.000 islands so that the enforcement of the law will be so challenging because the central government is located in Jakarta. Although the task force is made in every city in Indonesia, but the coordination between them will be really difficult if the government not monitoring regularly.

\footnotetext{
${ }^{9}$ Malcom N. Shaw QC, Hukum Internasional, Bandung, Nusamedia, 2013, 261

${ }^{10}$ Ibid
} 
Then what the government should do is to improve the regulation so that the laborer will be well-protected under the law. Indonesia needs to amend the Act number 13 year 2003 on manpower and explain about slavery-like practices so that all companies will not make any space to do a modern-day slavery. Governments should actively enforce the laws to ensure that all slaves, victims of forced labor, debt bondage and trafficking are free, and all slave holders, employer/enforcers and traffickers are prosecuted and required to pay damages to their victims.

Governments that ratify Conventions are obliged to incorporate them into their own laws and to make sure that these laws are applied and respected. The International conventions were ratified by Indonesia related to the Modern Slavery Practice, but as the writer stated above that the Slavery Convention and Supplementary Slavery convention has not been ratified by the Government. Indonesia should have to ratify those conventions so that Indonesia can implement it to national laws.

The government also needs to be regulated and monitoring regularly to make sure that the laws are enforced by the corporation. Indonesian government also should make an agency which concern to report regularly that if there is a violation, especially if there is a practice of forced labor or all-kinds of slavery in Indonesia, Creating a National Action Plan for trafficking in person, Establish Integrated Services for Witnesses and / or Victims of human trafficking in the District / City. Besides that, the Indonesian government should educate people since the factor of human trafficking caused by low education. To change and even to end the practice of slavery, what governments should have to give to people is education about what the slavery is, what the slavery-like practices, and in what forms the slavery in modern-day. When people educated about slavery, they at least will know whether they were treated like a slave or not and be reported to the government whether they are in a slavery condition or not. 


\section{IV.CONCLUSION}

Based on The Slavery Convention 1926 Article 1 (1), Slavery is the status or condition of a person over whom any or all of the powers attaching to the right of ownership are exercised. Slavery in Indonesia is regulated under the forced labor practice has to end. The government needs to ratify the slavery convention and the supplementary convention and implement those conventions in Indonesia. Besides, The Indonesian government should have to amend the regulation which is regulating about forced labor, or modern slavery practices. Indonesia also needs to educate people about slavery so they can know whether they are in slavery or not.

\section{REFERENCES}

Ann Jordan, 2011. SLAVERY, FORCED LABOR, DEBT BONDAGE, AND HUMAN TRAFFICKING: FROM CONCEPTIONAL CONFUSION TO TARGETED SOLUTIONS: USA : American University Washington College of Law

Annie Kelly, 2013. Modern-day Slavery: An Explainer. http://www.theguardian.com/globaldevelopment/2013/apr/03/modern-day-slavery-explainer

Fact Sheet No 14. Contemporarry Forms of Modern Slavery

Hukum Online, Jerat Hukum Bagi Pelaku Perbudakan :http://www.hukumonline.com/klinik/detail/lt5189e819260af/jerat-hukumbagi-pelaku-perbudakan

Malcom N. Shaw QC, 2013. Hukum Internasional. Bandung : Nusamedia

Rain Forest Action Network, 2014. Conflict Palm Oil in Practice : Exposing KLK's Role in Rainforest Destruction, Land Grabbing and Child Labor.

The Indonesian Act no 21 year 2007 concerning Eradication of the Criminal Act of the Trafficking in Persons

The Unofficial Translated of Act Number 13 Year 2003 concerning Manpower (ILO Jakarta)

United Nations Resources for Speakers on Global Issues : Child Labor Convention : *http://www.un.org/en/globalissues/briefingpapers/childlabour/intlconvs.shtml 
What

Is

Modern

Slavery,

*http://www.antislavery.org/english/slavery_today/what_is_modern_slavery.aspx

Walk Free Fondation, 2013. Global Slavery Index 2013

Walk Free Fondation, 2013. Global Slavery Index 2013 : Indonesia http://www.globalslaveryindex.org/country/indonesia/ 